\title{
Rapid synthesis of curcuminoid pyrazoles with antiviral effects through one-pot combinatorial modification of total curcuminoids
}

This article was published in the following Dove Press journal:

Research and Reports in Medicinal Chemistry

3 August 2015

Number of times this article has been viewed

\author{
Jie $\mathrm{Wu}^{1,2}$ \\ Hong-Jin Tang' \\ Jiao-Jiao $\mathrm{Xu}^{\prime}$ \\ Juan $\mathrm{Ye}^{3}$ \\ Hai-Yan Tian' \\ Yao-Lan $\mathrm{Li}^{\prime}$ \\ Ren-Wang Jiang ${ }^{1,4}$ \\ 'Institute of Traditional Chinese \\ Medicine and Natural Products, \\ College of Pharmacy, Jinan University, \\ Guangzhou, ${ }^{2}$ Department of Pharmacy, \\ Renmin Hospital of Wuhan University, \\ ${ }^{3}$ Department of Pharmacy, Hospital \\ of Huazhong University of Science \\ and Technology, Wuhan, ${ }^{4}$ Shenzhen \\ Engineering Laboratory of Lingnan \\ Herbal Resource Development and \\ Application, Shenzhen Institute for \\ Drug Control, Shenzhen, People's \\ Republic of China
}

Correspondence: Ren-Wang Jiang Institute of Traditional Chinese Medicine and Natural Products, College of Pharmacy, Jinan University, Guangzhou 510632, People's Republic of China Tel +86208522 1016

Email trwjiang@ jnu.edu.cn

\begin{abstract}
Four new curcuminoid pyrazoles (1-4) were synthesized by one-pot combinatorial modification of the total curcuminoid extract, through chemical transformation of $\beta$-diketone functionalities by $p$-chlorophenylhydrazine. All four curcuminoid pyrazoles were identified by spectroscopic methods, and the structure of compound $\mathbf{4}$ was further confirmed by single-crystal $\mathrm{X}$-ray analysis. Compounds $\mathbf{1}$ and $\mathbf{2}$, with a long conjugated system and at least one methoxy substitution, showed a more potent antiviral effect than did the corresponding natural product, curcumin. The rapid synthesis of curcuminoid pyrazoles with improved antiviral activity highlights the great potential of one-pot combinatorial modification for the diversification of natural products with improved bioactivities.
\end{abstract}

Keyword: curcumin, one-pot combinatorial modification, antiviral

\section{Introduction}

Curcuminoids are diarylheptanoids, mainly existing in the families Zingiberaceae and Betulaceae, etc. The skeletons are constructed by a heptane core with aryl groups substituted at the 1- and 7-positions. The most common representative compounds are curcumin, demethoxycurcumin, and bisdemethoxycurcumin. Curcuminoids have been shown to exhibit antioxidant, ${ }^{1}$ anti-inflammatory, ${ }^{2}$ anticancer, ${ }^{3}$ hypoglycemic, ${ }^{4}$ and anti-HIV ${ }^{5}$ bioactivities. In recent years, curcuminoid compounds have been used for the treatment of cardiovascular ${ }^{6-8}$ and Alzheimer's diseases, ${ }^{9}$ and clinical trials of curcumin as a therapeutic drug for advanced pancreatic cancer have been carried out in Phase II. ${ }^{10}$ Recently, curcumin was found to prevent the replication of respiratory syncytial virus (RSV). ${ }^{11}$ In addition, because of the color stability and very low toxicity, curcuminoids are widely used as food additives and coloring agents. Curcumin is safe even at a high dose of $8.0 \mathrm{~g} /$ day ${ }^{12}$ and oral consumption of curcumin up to $12 \mathrm{~g} /$ day is tolerable. ${ }^{13}$

However, the bioavailability of curcumin is poor, which limits its clinical application. ${ }^{14}$ Structural modification of curcumin has received attention worldwide and led to a number of bioactive curcumin derivatives. ${ }^{15-19}$ Among these derivatives, curcumin pyrazoles were found to show antimicrobial ${ }^{20}$ and antitumor activities. ${ }^{21,22}$ CNB-001, a pyrazole derivative of curcumin, was reported to exhibit neurotrophic activity, which can be used for the treatment of Parkinson's Disease and ischemic stroke. ${ }^{23-25}$

Currently, most structural modifications of curcuminoids focus on curcumin, a major component of Curcuma longa. Though there are a number of other minor natural curcumin analogs in C. longa, the structural modification of these minor components has not been reported because of limited quantities of starting materials. 
In recent years, increasing efforts have been invested in the application of one-pot combinatorial modification to create structural diversity, in which multiple starting materials and reactants are put in a single container to undergo chemical reactions. ${ }^{26-29}$ This approach can be regarded as "green" technology because it improves the efficiency of the chemical reaction and minimizes waste by abolishing complicated separation and purification of intermediates.

In this paper, the one-pot combinatorial modification strategy was used to diversify both the major and minor curcumin analogs, which resulted in four new curcuminoid pyrazoles (Figure1). These new derivatives showed more potent antiviral effects against RSV than did the natural product curcumin. We reported herein the modification strategy, structures of the curcuminoid pyrazoles, and the antiviral properties.

\section{Materials and methods}

Unless otherwise noted, reagents were purchased from commercial suppliers and used without further purification. Column chromatographies were performed on silica gel (200-400 mesh) (Qingdao Marine Chemical Plant, Qingdao, People's Republic of China), reverse-phase C18 silica gel (Merck KGaA, Darmstadt, Germany), and Sephadex ${ }^{\circledR}$ LH-20 (Pharmacia Biotec AB, Uppsala, Sweden). High-performance liquid chromatography (HPLC) analysis was carried out using an Agilent 1100 HPLC instrument, coupled to an Agilent 1100 diode array detector (DAD) (Agilent Technologies, Santa Clara, CA, USA); data were analyzed by using the Agilent ChemStation. Solvents used for column chromatography were of analytical grade (Shanghai Chemical Plant, Shanghai, People's Republic of China), and solvents used for HPLC were of chromatographic grade (Thermo Fisher Scientific Inc., Waltham, MA, USA). Ultraviolet (UV)-visible

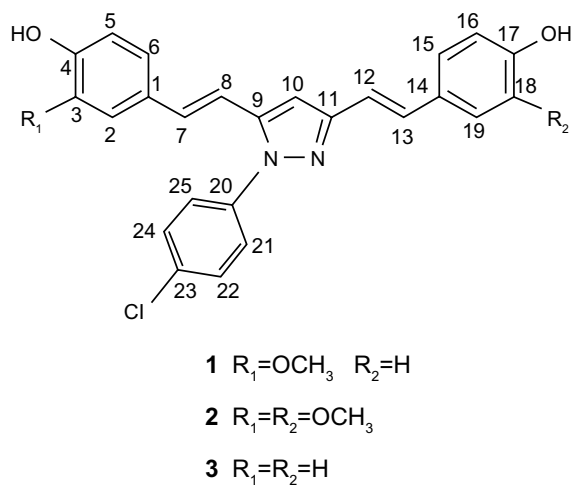

Figure I Structural formulae of compounds I-4.
(UV-Vis) absorption was recorded in $\mathrm{MeOH}$ on a JASCO V-550 UV/Vis spectrophotometer (JASCO Corp, Tokyo, Japan). Infrared (IR) absorption was recorded on a JASCO FT/IR-480 Plus Fourier transform infrared spectrometer using $\mathrm{KBr}$ pellet. Nuclear magnetic resonance (NMR) spectra, including ${ }^{1} \mathrm{H}-\mathrm{NMR},{ }^{13} \mathrm{C}-\mathrm{NMR}$, distortionless enhancement by polarization transfer (DEPT)-135 NMR, and two-dimensional (2D)-NMR spectra, were recorded on a Bruker AV-300 or AV-400 (Bruker Corporation, Billerica, MA, USA) spectrometer in dimethyl sulfoxide (DMSO), with tetramethylsilane as the internal reference, and the $\delta$ values, in ppm, were referenced to either the residual $\mathrm{CH}_{3} \mathrm{SOCH}_{3}$ (2.50 ppm) or $\mathrm{CD}_{3} \mathrm{SOCD}_{3}$ (39.5 ppm) signal. Electrospray ionization mass spectrometry (ESI-MS) spectra were carried out on a Finnigan LCQ Advantage Max ion trap mass spectrometer (Thermo Fisher Scientific Inc.). High-resolution (HR)-ESI-MS data were obtained on an Agilent 6210 ESI/ TOF mass spectrometer. Melting points were taken on a hotstage microscope (X-4; Beijing Taike Ltd, Beijing, People's Republic of China) and were uncorrected.

\section{Plant material}

The rhizomes of $C$. longa purchased in a Chinese medicinal herbs shop in Guangdong Province, People's Republic of China, in July 2010. The herbal material was identified at the Institute of Traditional Chinese Medicine and Nature Products, Jinan University, and a herbal specimen (number JH2010-1) was deposited.

\section{Enriching the total curcuminoids}

The dried rhizomes ( $5 \mathrm{~kg}$ ) were extracted with 95\% ethanol $(10 \mathrm{~L} \times 3)$, and the solvent was evaporated in vacuo to give crude extract $(650 \mathrm{~g})$. The crude extract was suspended in distilled water and extracted with ethyl acetate to afford the

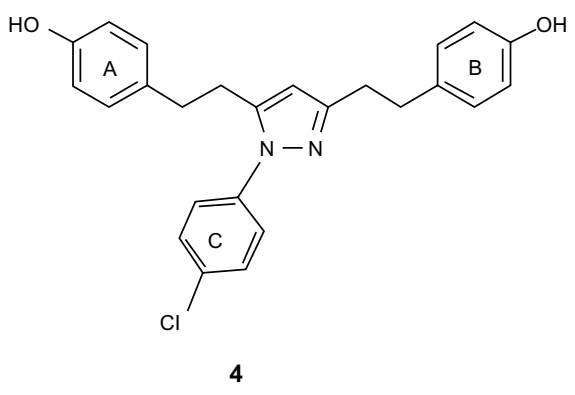


ethyl acetate fraction (474 g). Then the ethyl acetate fraction (100 g) was subjected to macroporous resin chromatography eluted with ethanol- $\mathrm{H}_{2} \mathrm{O}(30 \%, 70 \%$, and $95 \%)$. The $70 \%$ ethanol eluted fraction was condensed under vacuum to afford the total curcuminoids (54 g).

\section{Reaction of the total curcuminoids with p-chlorophenylhydrazine hydrochloride}

The total curcuminoids (20 g) was dissolved in glacial acetic acid $(200 \mathrm{~mL})$, and $p$-chlorophenylhydrazine hydrochloride $(20 \mathrm{~g})$ was added to the solution. The reaction mixture was stirred and refluxed for 12 hours. The resulting mixture was cooled to room temperature, and the solvent was evaporated in vacuo. The residue was dissolved in ethyl acetate and washed with distilled water to remove acetic acid, and the ethyl acetate layer was evaporated in vacuo to afford the semisynthetic mixture (30.4 g).

\section{Isolation of reaction products}

The semisynthetic mixture was subjected to silica gel (200-300 mesh) and eluted with cyclohexane-ethyl acetate $(100: 1,50: 1,30: 1,5: 1$, and 1:1) to give five fractions (fractions 1-5). Fraction 3 was separated by preparative HPLC and eluted with acetonitrile-water (45:55) to give compounds 1 (26 mg), 2 (105 mg), 3 (15 mg), and 4 (18 mg).

\section{I-(4-Chlorophenyl)-3-[2-(4-} hydroxyphenylethenyl)]-5-[2-(4-hydroxy3-methoxyphenylethenyl)]pyrazole (compound I)

White powder; UV (MeOH) $\lambda_{\text {max }}$ (loge): $325.2 \mathrm{~nm}$ (3.3); IR $(\mathrm{KBr}) v_{\max }: 3,396 \mathrm{~cm}^{-1}, 1,599 \mathrm{~cm}^{-1}, 1,505 \mathrm{~cm}^{-1}, 1,270 \mathrm{~cm}^{-1}$, $1,021 \mathrm{~cm}^{-1}, 826 \mathrm{~cm}^{-1}$; ESI-MS m/z: $445.5[\mathrm{M}+\mathrm{H}]^{+}, 443.6$ [M-H] $]^{-}, \mathrm{HR}-\mathrm{ESI}-\mathrm{MS} \mathrm{m} / \mathrm{z}: 445.13174[\mathrm{M}+\mathrm{H}]^{+}$(calcd for $\mathrm{C}_{26} \mathrm{H}_{22} \mathrm{ClN}_{2} \mathrm{O}_{3}$, requires 445.13135); ${ }^{1} \mathrm{H}$ NMR (400 MHz, DMSO- $\left.d_{6}\right): \delta(\mathrm{ppm}) 7.10(1 \mathrm{H}, \mathrm{d}, 1.6, \mathrm{H}-2), 6.78(1 \mathrm{H}, \mathrm{d}, 8.0$, H-5), 6.97 (1H, dd, 8.0, 1.6, H-6), 7.18 (1H, d, 16.0, H-7), 6.78 (1H, d, 16.0, H-8), 7.05 (1H, s, H-10), 6.94 (1H, d, 16.0, H-12), 7.16 (1H, d, 16.0, H-13), 7.43 (1H, d, 8.0, H-15), 6.79 $(1 \mathrm{H}, \mathrm{d}, 8.0, \mathrm{H}-16), 6.79$ (1H, d, 8.0, H-18), 7.43 (1H, d, 8.0, H-19), 7.56 (1H, dd, 8.0, 2.4, H-21), $7.62(1 \mathrm{H}, \mathrm{dd}, 8.0,1.6$, $\mathrm{H}-22), 7.62$ (1H, dd, 8.0, 1.6, H-24), 7.56 (1H, dd, 8.0, 2.4, $\mathrm{H}-25), 3.78$ (3H, s, H-26); ${ }^{13} \mathrm{C}$ NMR (100 MHz, DMSO- $\left.d_{6}\right)$ : $\delta$ (ppm) 127.8 (C-1), 110.7 (C-2), 147.8 (C-3), 147.4 (C-4), 115.7 (C-5), 120.4 (C-6), 133.3 (C-7), 112.0 (C-8), 142.6 (C-9), 101.1 (C-10), 151.4 (C-11), 116.9 (C-12), 130.7 (C-13),
127.8 (C-14), 127.9 (C-15), 115.6 (C-16), 157.4 (C-17), 115.6 (C-18), 127.9 (C-19), 138.1 (C-20), 126.3 (C-21), 129.4 (C-22), 131.9 (C-23), 129.4 (C-24), 126.3 (C-25), 55.7 (C-26).

\section{I-(4-Chlorophenyl)-3,5-bis[2-(4-hydroxy- 3-methoxyphenylethenyl)]pyrazole (compound 2)}

White powder; UV $(\mathrm{MeOH}) \lambda_{\text {max }}(\log \varepsilon): 240,330.4 \mathrm{~nm}$ (3.3); IR (KBr) $v_{\max }: 3,510 \mathrm{~cm}^{-1}, 1,600 \mathrm{~cm}^{-1}, 1,506 \mathrm{~cm}^{-1}$, $1,276 \mathrm{~cm}^{-1}, 1,022 \mathrm{~cm}^{-1}, 809 \mathrm{~cm}^{-1}$; ESI-MS $m / z: 475.4$ $[\mathrm{M}+\mathrm{H}]^{+}, 473.3[\mathrm{M}-\mathrm{H}]^{-}$, HR-ESI-MS m/z: $475.14198[\mathrm{M}+\mathrm{H}]^{+}$ (calcd for $\mathrm{C}_{27} \mathrm{H}_{24} \mathrm{ClN}_{2} \mathrm{O}_{4}$, requires 475.14191); ${ }^{1} \mathrm{H}$ NMR (400 MHz, DMSO- $\left.d_{6}\right): \delta(\mathrm{ppm}) 7.10(1 \mathrm{H}, \mathrm{d}, 1.6, \mathrm{H}-2), 6.78(1 \mathrm{H}$, d, 8.0, H-5), 6.97 (1H, dd, 8.0, 1.6, H-6), $7.18(1 \mathrm{H}, \mathrm{d}, 16.0$, $\mathrm{H}-7), 6.79(1 \mathrm{H}, \mathrm{d}, 16.0, \mathrm{H}-8), 7.05(1 \mathrm{H}, \mathrm{s}, \mathrm{H}-10), 7.01(1 \mathrm{H}$, d, 16.0, H-12), $7.16(1 \mathrm{H}, \mathrm{d}, 16.0, \mathrm{H}-13), 6.98(1 \mathrm{H}, \mathrm{d}, 8.0$, 2.0, H-15), $6.78(1 \mathrm{H}, \mathrm{d}, 8.0, \mathrm{H}-16), 7.21(1 \mathrm{H}, \mathrm{d}, 2.0, \mathrm{H}-19)$, $7.56(1 \mathrm{H}, \mathrm{dd}, 8.0,2.4, \mathrm{H}-21), 7.62(1 \mathrm{H}, \mathrm{dd}, 8.0,2.4, \mathrm{H}-22)$, $7.62(1 \mathrm{H}, \mathrm{dd}, 8.0,2.4, \mathrm{H}-24), 7.56(1 \mathrm{H}, \mathrm{dd}, 8.0,2.4, \mathrm{H}-25)$, 3.79 (3H, s, H-26), 3.83 (3H, s, H-27); ${ }^{13} \mathrm{C}$ NMR (100 MHz, DMSO- $\left.d_{6}\right): \delta(\mathrm{ppm}) 127.8(\mathrm{C}-1), 110.7(\mathrm{C}-2), 147.8(\mathrm{C}-3)$, 147.3 (C-4), 115.5 (C-5), 120.3 (C-6), 133.3 (C-7), 112.0 (C-8),142.6 (C-9), 101.1 (C-10), 151.4 (C-11), 117.2 (C-12), 131.0 (C-13), 128.3 (C-14), 120.4 (C-15), 115.6 (C-16), 146.8 (C-17), 147.9 (C-18), 109.7 (C-19), 138.1 (C-20), 126.3 (C-21), 129.4 (C-22), 131.9 (C-23), 129.4 (C-24), 126.3 (C-25), 55.6 (C-26), 55.7 (C-27).

\section{I-(4-Chlorophenyl)-3, 5-bis[2-(4- hydroxyphenylethenyl)]pyrazole (compound 3)}

White powder; UV (MeOH) $\lambda_{\text {max }}$ (loge): $323.4 \mathrm{~nm}$ (3.3); IR (KBr) $v_{\text {max }}: 3,192 \mathrm{~cm}^{-1}, 1,604 \mathrm{~cm}^{-1}, 1,506 \mathrm{~cm}^{-1}, 1,246 \mathrm{~cm}^{-1}$, $823 \mathrm{~cm}^{-1}$; ESI-MS m/z: $415.5[\mathrm{M}+\mathrm{H}]^{+}, 413.7[\mathrm{M}-\mathrm{H}]^{-}$, HRESI-MS $m / z$ : $415.12031[\mathrm{M}+\mathrm{H}]^{+}\left(\right.$calcd for $\mathrm{C}_{25} \mathrm{H}_{20} \mathrm{ClN}_{2} \mathrm{O}_{2}$, requires 415.12078); ${ }^{1} \mathrm{H}$ NMR (400 MHz, DMSO- $\left.d_{6}\right): \delta$ (ppm) $7.36(1 \mathrm{H}, \mathrm{d}, 8.0, \mathrm{H}-2), 6.77(1 \mathrm{H}, \mathrm{d}, 8.0, \mathrm{H}-3), 6.77$ $(1 \mathrm{H}, \mathrm{d}, 8.0, \mathrm{H}-5), 7.36(1 \mathrm{H}, \mathrm{d}, 8.0, \mathrm{H}-6), 7.19(1 \mathrm{H}, \mathrm{d}, 16.0$, H-7), $6.72(1 \mathrm{H}, \mathrm{d}, 16.0, \mathrm{H}-8), 7.07(1 \mathrm{H}, \mathrm{s}, \mathrm{H}-10), 6.94(1 \mathrm{H}, \mathrm{d}$, 16.0, H-12), 7.16 (1H, d, 16.0, H-13), $7.43(1 \mathrm{H}, \mathrm{d}, 8.0, \mathrm{H}-15)$, $6.78(1 \mathrm{H}, \mathrm{d}, 8.0, \mathrm{H}-16), 6.78(1 \mathrm{H}, \mathrm{d}, 8.0, \mathrm{H}-18), 7.43(1 \mathrm{H}, \mathrm{d}$, 8.0, H-19), 7.55 (1H, dd, 8.0, 2.0, H-21), $7.62(1 \mathrm{H}, \mathrm{dd}, 8.0$, 2.0, H-22), 7.62 (1H, dd, 8.0, 2.0, H-24), $7.55(1 \mathrm{H}, \mathrm{dd}, 8.0$, 2.0, H-25); ${ }^{13} \mathrm{C}$ NMR (100 MHz, DMSO- $\left.d_{6}\right): \delta(\mathrm{ppm}) 127.2$ (C-1), 128.3 (C-2), 115.6 (C-3), 157.9 (C-4), 115.6 (C-5), 128.3 (C-6), 132.8 (C-7), 111.6 (C-8), 142.5 (C-9), 100.9 
(C-10), 151.3 (C-11), 116.9 (C-12), 130.7 (C-13), 127.8

(C-14), 127.9 (C-15), 115.6 (C-16), 157.4 (C-17), 115.6

(C-18), 127.9 (C-19), 138.1 (C-20), 126.5 (C-21), 129.4

(C-22), 132.0 (C-23), 129.4 (C-24), 126.5 (C-25).

\section{I-(4-Chlorophenyl)-3, 5-bis[2-(4- hydroxyphenylethyl)]pyrazole (compound 4)}

Colorless crystals (from methanol solution); (MeOH), melting point $110^{\circ} \mathrm{C} \sim 111^{\circ} \mathrm{C}$; $\mathrm{UV}(\mathrm{MeOH}) \lambda_{\text {max }}(\log \varepsilon): 250.4 \mathrm{~nm}$ (1.7); IR (KBr) $v_{\max }: 3,404 \mathrm{~cm}^{-1}, 1,644 \mathrm{~cm}^{-1}, 1,522 \mathrm{~cm}^{-1}$, $1,022 \mathrm{~cm}^{-1}$; ESI-MS m/z: $419.3[\mathrm{M}+\mathrm{H}]^{+}, 417.2[\mathrm{M}-\mathrm{H}]^{-}$, HRESI-MS $m / z$ : $419.15261[\mathrm{M}+\mathrm{H}]^{+}$(calcd for $\mathrm{C}_{25} \mathrm{H}_{24} \mathrm{ClN}_{2} \mathrm{O}_{2}$, requires 419.15208); ${ }^{1} \mathrm{H}$ NMR (400 $\left.\mathrm{MHz}, \mathrm{DMSO}-d_{6}\right)$ : $\delta(\mathrm{ppm}) 6.92(1 \mathrm{H}, \mathrm{d}, 8.0, \mathrm{H}-2), 6.63(1 \mathrm{H}, \mathrm{dd}, 8.0,2.0, \mathrm{H}-3)$, $6.63(1 \mathrm{H}, \mathrm{dd}, 8.0,2.0, \mathrm{H}-5), 6.92(1 \mathrm{H}, \mathrm{d}, 8.0, \mathrm{H}-6), 2.70(2 \mathrm{H}$, t, H-7), $2.85(2 \mathrm{H}, \mathrm{t}, \mathrm{H}-8), 6.18(1 \mathrm{H}, \mathrm{s}, \mathrm{H}-10), 2.78(2 \mathrm{H}, \mathrm{t}$, $\mathrm{H}-12), 2.78$ (2H, t, H-13), 7.03 (1H, d, 8.0, H-15), $6.67(1 \mathrm{H}$, dd, 8.0, 2.0, H-16), $6.67(1 \mathrm{H}, \mathrm{dd}, 8.0,2.0, \mathrm{H}-18), 7.03(1 \mathrm{H}$, d, 8.0, H-19), $7.43(1 \mathrm{H}, \mathrm{dd}, 8.0,2.0, \mathrm{H}-21), 7.52(1 \mathrm{H}, \mathrm{dd}$, 8.0, 2.0, H-22), 7.52 (1H, dd, 8.0, 2.0, H-24), $7.43(1 \mathrm{H}, \mathrm{dd}$, 8.0, 2.0, H-25); ${ }^{13} \mathrm{C}$ NMR (100 MHz, DMSO- $\left.d_{6}\right): \delta(\mathrm{ppm})$ 130.8 (C-1), 129.1 (C-2), 114.9 (C-3), 155.5 (C-4), 114.9 (C-5), 129.1 (C-6), 33.2 (C-7), 28.1 (C-8), 143.4 (C-9), 105.2 (C-10), 152.4 (C-11), 30.0 (C-12), 34.1 (C-13), 131.7 (C-14), 129.1 (C-15), 115.0 (C-16), 155.3 (C-17), 115.0 (C-18), 129.1 (C-19), 138.5 (C-20), 126.3 (C-21), 129.0 (C-22), 131.6 (C-23), 129.0 (C-24), 126.3 (C-25).

\section{X-ray crystallographic analysis of compound 4}

Data were collected using an Agilent Sapphire CCD with a $\mathrm{CuK} \alpha$ radiation, $\lambda=1.54184 \AA$ at $173.00(2) \mathrm{K}$. Crystal data: $\mathrm{C}_{25} \mathrm{H}_{23} \mathrm{ClO}_{2} \mathrm{~N}_{2}$, monoclinic, space group $\mathrm{P} 2 / \mathrm{n}$; unit cell dimensions were determined to be $a=13.2127(2) \AA, b=11.4770$ (2) $\AA, c=14.3049(2) \AA, \beta=98.821(1)^{\circ}, V=2,143.57(6) \AA^{3}, Z=4$, $\mathrm{Dx}=1.298 \mathrm{~g} / \mathrm{cm}^{3}, F(000)=880, \mu(\mathrm{CuK \alpha})=1.765 \mathrm{~mm}^{-1}$. A total 6,159 reflections were collected until $\theta_{\text {max }}=61.07^{\circ}$, in which independent unique 2,509 reflections were observed $\left[F^{2}>4 \sigma\left(F^{2}\right)\right]$. The structure was solved by direct methods using the SHELXS-97 program. The final refinement gave $R=0.0691, R w=0.0834$, and $S=1.116$. Crystal data of compound 4 was deposited with the Cambridge Crystallographic Data Centre (CCDC) (CCDC 976559). Copies of the data can be obtained free of charge on application to CCDC, 12 Union Road, Cambridge CB2 1EZ, UK (Fax: +44 1223 336033; Email: deposit@ccdc.cam.ac.uk).

\section{Antiviral assay}

The cytopathic effects (CPE) reduction method was used. ${ }^{30}$ Briefly, HEp-2 cells (American Type Culture Collection, Manassas, VA, USA) were cultured in 96-well plates and incubated at $37^{\circ} \mathrm{C}$ in a humidified atmosphere supplied with $5 \% \mathrm{CO}_{2}$. To the confluent cell monolayers in 96-well plates, a fixed quantity of RSV virus (American Type Culture Collection) (50\% tissue culture infective dose [TCID50] $=100$ ) in suspension was added to the monolayers of HEp-2 cells. The samples were dissolved in DMSO and were serially twofold diluted with the assay buffer (final DMSO concentration was less than $0.1 \%$ ). After the samples were added, the plates were incubated at $37^{\circ} \mathrm{C}$ in a humidified $\mathrm{CO}_{2}$ atmosphere for 4-6 days. The virus-induced CPE were scored under light microscopy in comparison with the virus control. The maximal concentration without cytotoxic effect was defined as the maximal noncytotoxic concentration (MNCC). The concentration that showed $50 \%$ cytotoxic effect was defined as $\mathrm{CC}_{50}$. The concentration of the sample that reduced $50 \%$ of $\mathrm{CPE}$ with respect to the virus control was estimated from the plots of the data and was defined as the $50 \%$ inhibitory concentration $\left(\mathrm{IC}_{50}\right)$. The selectivity against RSV virus was characterized by the therapeutic index (TI)

$$
\mathrm{TI}=\mathrm{CC}_{50} / \mathrm{IC}_{50} \text {. }
$$

\section{Results and discussion}

The D101 macroporous resin was used to enrich the total curcuminoids from the ethyl acetate extract of $C$. longa. Then the total curcuminoids was reacted with $p$-chlorophenylhydrazine to afford a semisynthetic mixtures, which showed antiviral effect against RSV, with an $\mathrm{IC}_{50}$ value of $25 \mu \mathrm{g} / \mathrm{mL}$. The subsequent isolation resulted in four new curcuminoid pyrazoles (1-4).

The HS-ESI-MS of 1 showed a pseudomolecular ion $m / z: 445.13174[\mathrm{M}+\mathrm{H}]^{+}$(calcd for 445.13135), indicating a molecular formula of $\mathrm{C}_{26} \mathrm{H}_{21} \mathrm{ClN}_{2} \mathrm{O}_{3}$. A maximum $\mathrm{UV}$ absorbance peak was observed at $325 \mathrm{~nm}$ in the UV spectrum, indicating the presence of a long conjugated system. The IR spectrum revealed aromatic rings $\left(1,599 \mathrm{~cm}^{-1}\right.$ and $\left.1,505 \mathrm{~cm}^{-1}\right)$ and hydroxyl groups $\left(3,396 \mathrm{~cm}^{-1}\right)$. The ${ }^{1} \mathrm{H}$ NMR spectrum of 1 showed the signals from a $p$-chloro-substituted benzene ring moiety $\left[\delta_{\mathrm{H}} 7.62(2 \mathrm{H}, \mathrm{dd}, J=8.0,1.6 \mathrm{~Hz}), 7.56\right.$ $(2 \mathrm{H}, \mathrm{dd}, J=8.0,2.4 \mathrm{~Hz})]$, a $p$-hydroxy-substituted benzene ring $\left[\delta_{\mathrm{H}} 7.43(2 \mathrm{H}, \mathrm{d}, J=8.0 \mathrm{~Hz}), 6.79(2 \mathrm{H}, \mathrm{d}, J=8.0 \mathrm{~Hz})\right]$, a $1,3,4$-trisubstituted benzene ring $\left[\delta_{\mathrm{H}} 7.10(1 \mathrm{H}, \mathrm{d}, J=1.6 \mathrm{~Hz})\right.$, $6.97(1 \mathrm{H}, \mathrm{dd}, J=8.0,1.6 \mathrm{~Hz}), 6.78(1 \mathrm{H}, \mathrm{d}, J=8.0 \mathrm{~Hz})]$, 
two trans double bonds $\left[\delta_{\mathrm{H}} 7.18(1 \mathrm{H}, \mathrm{d}, J=16.0 \mathrm{~Hz}), 6.78\right.$ $(1 \mathrm{H}, \mathrm{d}, J=16.0 \mathrm{~Hz}), 7.16(1 \mathrm{H}, \mathrm{d}, J=16.0 \mathrm{~Hz}), 6.94(1 \mathrm{H}, \mathrm{d}$, $J=16.0 \mathrm{~Hz})$ ], an olefinic proton signal in pyrazole ring $\delta_{\mathrm{H}}$ $7.05(1 \mathrm{H}, \mathrm{s})$ and a methoxy signal $\delta_{\mathrm{H}} 3.78(3 \mathrm{H}, \mathrm{s})$. The ${ }^{13} \mathrm{C}$ NMR and DEPT-135 spectra of $\mathbf{1}$ confirmed the presence of the pyrazole ring moiety $\left(\delta_{\mathrm{C}} 142.6,101.1,151.4\right)$ and agreed well with the ${ }^{1} \mathrm{H}$ NMR data. Detailed NMR assignments were done through analysis of its 2D NMR spectra. Accordingly, compound $\mathbf{1}$ was identified as 1-(4chlorophenyl)-3-[2-(4-hydroxyphenylethenyl)]-5-[2-(4hydroxy-3-methoxyphenylethenyl)]pyrazole, which was derived from demethoxycurcumin.

The molecular formula of 2 was established as $\mathrm{C}_{27} \mathrm{H}_{23} \mathrm{ClN}_{2} \mathrm{O}_{4}$ based on the pseudomolecular ion $m / z$ : $475.14198[\mathrm{M}+\mathrm{H}]^{+}$ (calcd for 475.14191), which had one more methoxy group than 1 . The ${ }^{1} \mathrm{H}$ and ${ }^{13} \mathrm{C}-\mathrm{NMR}$ spectra of 2 showed that there were two methoxy groups $\left(\delta_{\mathrm{H}} 3.79, \delta_{\mathrm{C}} 55.6\right.$; $\left.\delta_{\mathrm{H}} 3.83, \delta_{\mathrm{C}} 55.7\right)$, which was consistent with the ESI-MS data. Considering the conserved methoxy substitution pattern in natural curcuminoids, compound $\mathbf{2}$ could be identified as 1-(4-chlorophenyl)-3,5-bis[2-(4-hydroxy-3methoxyphenylethenyl)]pyrazole, which was derived from curcumin.

The HS-ESI-MS of $\mathbf{3}$ showed a pseudomolecular ion $\mathrm{m} / \mathrm{z}: 415.12031[\mathrm{M}+\mathrm{H}]^{+}$(calcd for 415.12078), indicating a molecular formula of $\mathrm{C}_{25} \mathrm{H}_{19} \mathrm{ClN}_{2} \mathrm{O}_{2}$, which had one less methoxy group than 1 . The ${ }^{1} \mathrm{H}$ and ${ }^{13} \mathrm{C}$-NMR spectra of 3 were similar to those of $\mathbf{1}$ except that no methoxy signal was observed, which was consistent with the ESI-MS data. The $\mathrm{AA}^{\prime} \mathrm{BB}^{\prime}$ coupling patterns also confirmed that the benzene rings were all monosubstituted. Accordingly, compound 3 was identified as 1-(4-chlorophenyl)-3,5-bis[2-(4-hydroxyphenylethenyl)]pyrazole, which was the reaction product of bisdemethoxycurcumin.

The molecular formula of $\mathbf{4}$ was established as $\mathrm{C}_{25} \mathrm{H}_{23} \mathrm{ClN}_{2} \mathrm{O}_{2}$ based on the pseudomolecular ion $\mathrm{m} / \mathrm{z}$ : 419.15261 [M+H] $]^{+}$(calcd for 419.15208), which had four more protons than that of 3 . The ${ }^{1} \mathrm{H}$ and ${ }^{13} \mathrm{C}-\mathrm{NMR}$ spectra of $\mathbf{4}$ were similar to those of $\mathbf{3}$, except that two trans double bonds in 3 were replaced by four methylenes $\left[\delta_{\mathrm{H}} 2.70\right.$, 2H, t (H-7); C-7: 33.2; H-8: 2.85, 2H, t; C-8: 28.1; H-12: 2.78, 2H, t; C-12: 30.0; H-13: 2.78 2H, t; and C-13: 34.1]. Similar to 3, no methoxy signal was observed in the NMR spectra of 4 . Accordingly, compound 4 was identified as 1-(4chlorophenyl)-3,5-bis [2-(4-hydroxyphenylethyl)]pyrazole, which was the reaction product of tetrahydrobisdemethoxycurcurcumin. Furthermore, the molecular structure of $\mathbf{4}$ was confirmed by X-ray crystallographic analysis (Figure 2).

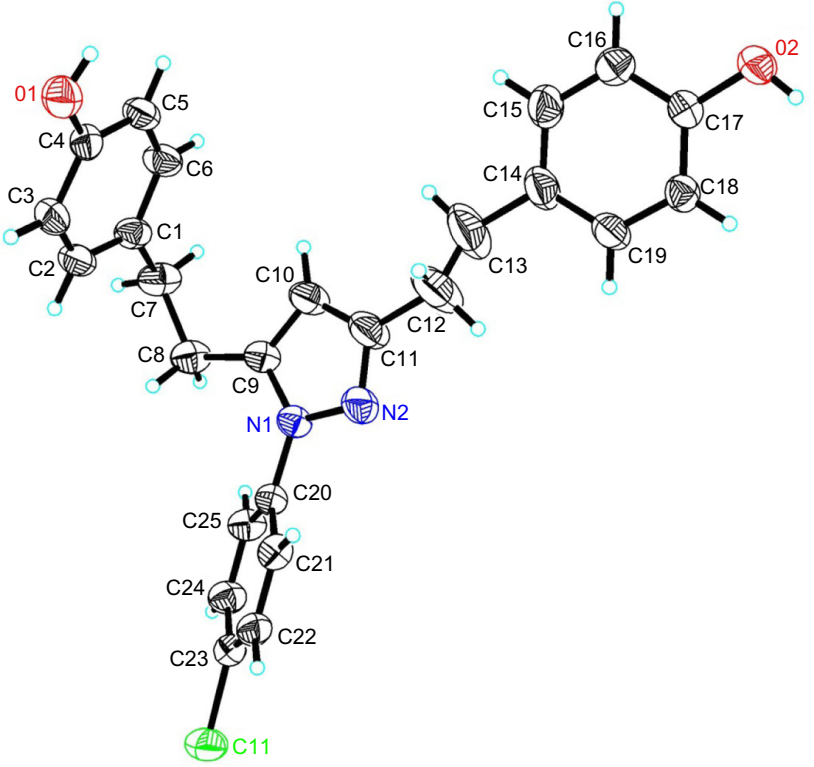

Figure $\mathbf{2}$ X-ray structure of compound $\mathbf{4}$ showing the atom labeling scheme. Note: The C, N, O and $\mathrm{Cl}$ atoms are drawn as $30 \%$ thermal ellipsoids.

In solid state, the benzene rings $\mathrm{A}$ and $\mathrm{B}$ had dihedral angles of $55.8^{\circ}$ and $100.3^{\circ}$ with the $p$-chlorophenyl moiety (ring C), respectively.

The curcuminoid pyrazoles $\mathbf{1}-\mathbf{4}$ were tested for the antiviral effects against RSV (Table 1). Both compounds $\mathbf{1}$ and 2, with a long conjugated system and at least one methoxy substitution, showed similar antiviral effects, with an $\mathrm{IC}_{50}$ value of $12.5 \mu \mathrm{M}$, which is much more potent than the natural product, curcumin $\left(\mathrm{IC}_{50}>50 \mu \mathrm{M}\right)$. Though $\mathbf{1}$ and $\mathbf{2}$ showed similar potency, the MNCC of $\mathbf{2}$ was twofold higher than that of $\mathbf{1}$, indicating a much higher safety of $\mathbf{2}$. Compounds $\mathbf{3}$ and 4 were inactive at $50 \mu \mathrm{M}$, indicating that the conjugated system, methoxy substitution, and chlorophenyl substituted pyrazole ring might be beneficial to the antiviral property. It is noteworthy that the cytotoxic effects of $\mathbf{1 - 4}$ were tested against prostate cancer cells (PC3 and LNCaP); however all these derivatives demonstrated decreased activities as compared with those of curcumin. ${ }^{31}$

Table I The antiviral effects of compounds I-4

\begin{tabular}{lllll}
\hline Compound & MNCC $(\mu \mathrm{M})$ & $\mathrm{CC}_{50}(\mu \mathrm{M})$ & $\mathrm{IC}_{50}(\mu \mathrm{M})$ & $\mathrm{TI}$ \\
\hline $\mathbf{I}$ & 12.5 & 50.0 & 12.5 & 4 \\
$\mathbf{2}$ & 25.0 & 50.0 & 12.5 & 4 \\
$\mathbf{3}$ & $<12.5$ & $<12.5$ & $>50.0$ & $<\mathrm{I}$ \\
$\mathbf{4}$ & $<\mathrm{I} 2.5$ & $<12.5$ & $>50.0$ & $<\mathrm{I}$ \\
Curcumin & $>12.5$ & 20.0 & $>50.0$ & $<\mathrm{I}$ \\
\hline
\end{tabular}

Note: $\mathrm{TI}=\mathrm{CC}_{50} / \mathrm{IC}_{50^{\circ}}$

Abbreviations: $\mathrm{CC}_{50}$, the concentration that showed $50 \%$ cytotoxic effect; $1 \mathrm{I}_{50}$ $50 \%$ inhibition concentration; MNCC, maximal noncytotoxic concentration; Tl, therapeutic index. 


\section{Conclusion}

In summary, four new curcuminoid pyrazoles (1-4) were rapidly synthesized by combinatorial modification of the total curcuminoid extract of $C$. longa. Among these curcuminoid pyrazoles, compound $\mathbf{2}$ was the only one derived from the major component curcumin; while compounds $\mathbf{1}, \mathbf{3}$, and $\mathbf{4}$ were derived from the minor components demethoxycurcumin bisdemethoxycurcumin and tetrahydrobisdemethoxycurcurcumin, respectively. If the conventional structural modification strategy - starting first with extraction and purification of these minor components, followed by chemical modification - is employed, it will be time-consuming and cost ineffective. Furthermore, compounds $\mathbf{1}$ and $\mathbf{2}$, with a long conjugated system and at least one methoxy substitution, showed more potent antiviral effect than did the corresponding natural product, curcumin. The rapid synthesis of curcuminoid pyrazoles with improved antiviral activity highlights the great potential of one-pot combinatorial modification for the diversification of natural products with improved bioactivities.

\section{Acknowledgments}

This work was supported by the Doctoral Fund of Ministry of Education, People's Republic of China (grant number 20114401110005) and the Independent Research Project of Wuhan University, People's Republic of China (grant number 2042014kf0159).

\section{Disclosure}

The authors report no conflicts of interest in this work.

\section{References}

1. Venkatesan P, Rao MN. Structure-activity relationships for the inhibition of lipid peroxidation and the scavenging of free radicals by synthetic symmetrical curcumin analogues. $J$ Pharm Pharmacol. 2000;52(9):1123-1128.

2. Srimal RC, Dhawan BN. Pharmacology of diferuloyl methane (curcumin), a non-steroidal anti-inflammatory agent. JPharm Pharmacol. 1973;25(6):447-452.

3. Huang MT, Lou YR, Ma W, Newmark HL, Reuhl KR, Conney AH. Inhibitory effects of dietary curcumin on forestomach, duodenal, and colon carcinogenesis in mice. Cancer Res. 1994;54(22):5841-5847.

4. Arun N, Nalini N. Efficacy of turmeric on blood sugar and polyol pathway in diabetic albino rats. Plant Foods Hum Nutr. 2002;57(1):41-52.

5. Sui Z, Salto R, Li J, Craik C, Ortiz de Montellano PR. Inhibition of the HIV-1 and HIV-2 proteases by curcumin and curcumin boron complexes. Bioorg Med Chem. 1993;1(6):415-422.

6. Quiles JL, Mesa MD, Ramírez-Tortosa CL, et al. Curcuma longa extract supplementation reduces oxidative stress and attenuates aortic fatty streak development in rabbits. Arterioscler Thromb Vasc Biol. 2002;22(7): 1225-1231.

7. Morimoto T, Sunagawa Y, Kawamura T, et al. The dietary compound curcumin inhibits p300 histone acetyltransferase activity and prevents heart failure in rats. $J$ Clin Invest. 2008;118(3):868-878.
8. Wongcharoen W, Phrommintikul A. The protective role of curcumin in cardiovascular diseases. Int J Cardiol. 2009;133(2):145-151.

9. Mishra S, Palanivelu K. The effect of curcumin (turmeric) on Alzheimer's disease: An overview. Ann Indian Acad Neurol. 2008; 11(1):13-19.

10. Dhillon N, Aggarwal BB, Newman RA, et al. Phase II trial of curcumin in patients with advanced pancreatic cancer. Clin Cancer Res. 2008;14(14):4491-4499.

11. Obata K, Kojima T, Masaki T, et al. Curcumin prevents replication of respiratory syncytial virus and the epithelial responses to it in human nasal epithelial cells. PLoS One. 2013;8(9):e70225.

12. Cheng AL, Hsu CH, Lin JK, et al. Phase I clinical trial of curcumin, a chemopreventive agent, in patients with high-risk or pre-malignant lesions. Anticancer Res. 2001;21(4B):2895-2900.

13. Heger M, van Golen RF, Broekgaarden M, Michel MC. The molecular basis for the pharmacokinetics and pharmacodynamics of curcumin and its metabolites in relation to cancer. Pharmacol Rev. 2014;66(1): 222-307.

14. Anand P, Kunnumakkara AB, Newman RA, Aggarwal BB. Bioavailability of curcumin: problems and promises. Mol Pharm. 2007;4(6):807-818.

15. Mishra S, Kapoor N, Mubarak Ali A, et al. Differential apoptotic and redox regulatory activities of curcumin and its derivatives. Free Radic Biol Med. 2005;38(10):1353-1360.

16. Costi R, Di Santo R, Artico M, et al. Cinnamoyl compounds as simple molecules that inhibit p300 histone acetyltransferase. J Med Chem. 2007;50(8):1973-1977.

17. Zhang Q, Fu Y, Wang HW, Gong T, Qin Y, Zhang ZR. Synthesis and cytotoxic activity of novel curcumin analogues. Chin Chem Lett. 2008;19(3):281-285.

18. Qiu X, Du Y, Lou B, et al. Synthesis and identification of new 4-arylidene curcumin analogues as potential anticancer agents targeting nuclear factor- $\mathrm{kB}$ signaling pathway. $J$ Med Chem. 2010;53(23): 8260-8273.

19. Huo YP, Shao WY, An LK, Bu XZ, Gu LQ. Synthesis of new 2-aryl-6styryl-2, 3-dihydropyridin-4(1H)-one derivatives from curcuminoids. Chin Chem Lett. 2009;20(11):1291-1295.

20. Sahu PK, Sahu PK, Gupta SK, Thavaselvam D, Agarwal DD. Synthesis and evaluation of antimicrobial activity of $4 \mathrm{H}$-pyrimido[2,1-b]benzothiazole, pyrazole and benzylidene derivatives of curcumin. Eur J Med Chem. 2012;54:366-378.

21. Labbozzetta M, Baruchello R, Marchetti P, et al. Lack of nucleophilic addition in the isoxazole and pyrazole diketone modified analogs of curcumin; implications for their antitumor and chemosensitizing activities. Chem Biol Interact. 2009;181(1):29-36.

22. Fuchs JR, Pandit B, Bhasin D, et al. Structure-activity relationship studies of curcumin analogues. Bioorg Med Chem Lett. 2009;19(7): 2065-2069.

23. Jayaraj RL, Tamilselvam K, Manivasagam T, Elangovan N. Neuroprotective effect of CNB-001, a novel pyrazole derivative of curcumin on biochemical and apoptotic markers against rotenone-induced SK-N-SH cellular model of Parkinson's disease. J Mol Neurosci. 2013;51(3):863-870.

24. Mayadevi M, Sherin DR, Keerthi VS, Rajasekharan KN, Omkumar RV. Curcumin is an inhibitor of calcium/calmodulin dependent protein kinase II. Bioorg Med Chem. 2012;20(20):6040-6047.

25. Lapchak PA, Schubert DR, Maher PA. Delayed treatment with a novel neurotrophic compound reduces behavioral deficits in rabbit ischemic stroke. J Neurochem. 2011;116(1):122-131.

26. López SN, Ramallo IA, Sierra MG, Zacchino SA, Furlan RL. Chemically engineered extracts as an alternative source of bioactive natural productlike compounds. Proc Natl Acad Sci U S A. 2007;104(2):441-444.

27. Méndez L, Salazar MO, Ramallo IA, Furlan RL. Brominated extracts as source of bioactive compounds. ACS Comb Sci. 2011;13(2):200-204.

28. Wang SY, Kuo YH, Chang HN, et al. Profiling and characterization antioxidant activities in Anoectochilus formosanus hayata. JAgric Food Chem. 2002;50(7):1859-1865. 
29. Kikuchi H, Sakurai K, Oshima Y. Development of diversity-enhanced extracts of Curcuma zedoaria and their new sesquiterpene-like compounds. Org Lett. 2014;16(7):1916-1919.

30. Li Y, Ooi LS, Wang H, But PP, Ooi VE. Antiviral activities of medicinal herbs traditionally used in southern mainland China. Phytother Res. 2004;18(9):718-722.
31. Wu J. Studies on Natural Curcuminoids and their Combinatorial Modification [doctoral thesis]. Guangzhou: Jinan University; 2012.

Research and Reports in Medicinal Chemistry

\section{Publish your work in this journal}

Research and Reports in Medicinal Chemistry is an international, peerreviewed, open access journal publishing original research, reports, reviews and commentaries on all areas of medicinal chemistry. The manuscript management system is completely online and includes a very quick and fair peer-review system, which is all easy to use.
Visit http://www.dovepress.com/testimonials.php to read real quotes from published authors.

\footnotetext{
Submit your manuscript here: http://www.dovepress.com/research-and-reports-in-medicinal-chemistry-journal
} 